TITLE:

\title{
NOTEWORTHY ALGAE FROM TAKARAZIMA ISLAND
}

$\operatorname{AUTHOR}(\mathrm{S})$ :

Ogata, Eizi

\section{CITATION:}

Ogata, Eizi. NOTEWORTHY ALGAE FROM TAKARAZIMA ISLAND.

PUBLICATIONS OF THE SETO MARINE BIOLOGICAL LABORATORY 1956, 5(2): 283-289

\section{ISSUE DATE:}

1956-06-30

URL:

http://hdl.handle.net/2433/174551

RIGHT: 


\title{
NOTEWORTHY ALGAE FROM TAKARAZIMA ISLAND ${ }^{1)}$
}

\author{
EizI OGATA \\ Biological Department, Institute of Polytechnics, Osaka City University
}

With 5 Text-figures

Of the ten scattered islands of the Tokara Islands, Takarazima (Pennel or Roy Island) and Nakanosima (Pinnacle Island) were visited by a scientific expedition during the period from May 26 to June 12, 1953. The expedition, associated under the management of Mr. Yoshitaka Tsutsur, director of the Osaka Municipal Museum of Natural History, visited first Takarazima, the southernmost one (about $29^{\circ} \mathrm{N}$ ) of this islands and next Nakanosima, nearly situated to the northern end of this islands group (about $30^{\circ} \mathrm{N}$ ).

I was fortunately in this group of scientists and had an opportunity to collect and study marine algae in the intertidal zone of these islands. These islands had scarcely been visited by any other phycologist except T. TANAKA (1952), therefore this study was of great interest to me.

I wish to express here my hearty thanks to Dr. S. SEgawa for his kind advice and to Prof. S. Miki and Dr. Y. YonedA for their continuous encouragements.

Takarazima has well developed fringing reefs so that algal vegetation is relatively more thriving than at Nakanosima which has poor fringing reef and steep cliffs. Moreover, weather was relatively better at Takarazima than at Nakanosima in the beginning of rainy season, so algal materials collected were ample at the former island. As algal flora was in fact very poor both in vegetation and in number of species at Nakanosima, most of noteworthy algae were obtained at Takarazima mainly. Roughly comparing these two islands, the tropical feature in flora was more conspicuous at Takarazima than at Nakanosima. The feature of shore and ecological zonation of faunae and florae in the intertidal zone of Takarazima were described in detail in the paper of T. TokiokA (1953). ${ }^{2)}$ Among four noteworthy algae dealt with in the present paper, one is new to Japan.

1) Scientific Survey of the Tokara Islands, Report No. 24.

2) T. TokrokA: Invertebrate fauna of the intertidal zone of the Tokara Islands I. Introductory notes, with the outline of the shore and the fauna. Publ. Seto Mar. Biol. Lab., Vol. III, No. 2., Dec., 1953.

Publ. Seto Mar. Biol. Lab., V (2), 1956. (Article 17) 


\section{Acetabularia (Polyphysa) exigua SOLMS}

(Fig. 1)

Monogr. of Acetabularia. (Trans. of Linn. Soc. London, 2nd Ser., Vol. 5, 1895) p. 28, pl. 2, figs. 1, 4 ; Weber van Bosse, Liste des Alg. du Siboga, Vol. 1. (1913) p. 91 ; YAmada, Mar. Chlorophyc. Ryukyu (1934) p. 55.

Japanese Name. Hosigata-kasanori.

Only three specimens were collected together with abundant specimens of Acetabularia Möbii Solms on coral reef at low tide. The plant is very small. Its stem is

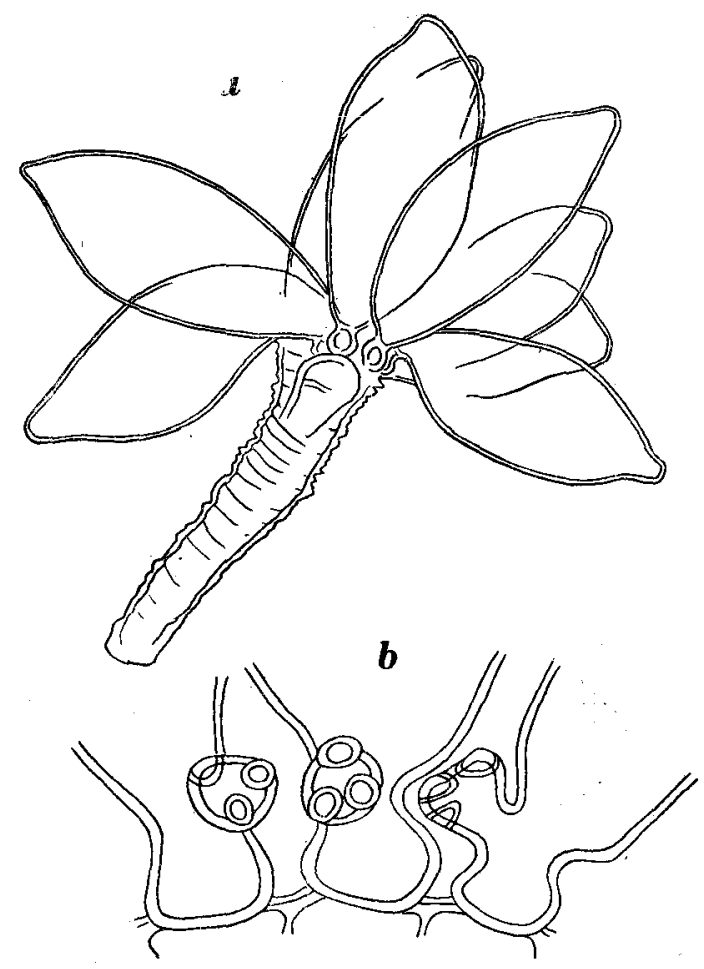

Fig. 1. Acetabularia exigua Solms.

a. Side view. $\times 35$

$b$. View of the corona superior from above. $\times 130$

solitary and $1.5-2 \mathrm{~mm}$ in height, and particularly in the upper part there are many dense annular furrows arranged parallel. The disc is about $2 \mathrm{~mm}$ in diameter and has $8-9$ rays. The rays, free from each other, are-spindle shaped and have peaked tips. The corona inferior is absent. The corona superior bears three hairs or hair scars. All specimens are sterile. 


\section{Pseudobryopsis hainanensis TSENG}

(Figs. 2 and 3)

Studies Mar. Chlorophyc. from Hainan (1936), p. 171 figs. 27, 28; DAwson, Mar. Flora Isla San Benedicto Following the Volcanic Eruption of 1952-1953 (1954), p. 9, pl. 3, figs. 2-4.

Japanese Name. Hanemo-modoki (nov.).

This species has hitherto been discovered only at Hainan Island, South China, and Isla San Benedicto, on the opposite side of the Pacific Ocean. The specimens collected are only a few tufts during the sojourn at Takarazima. These were so inconspicuous that the exact habitat of the thallus was overlooked during the collecting. Presumably these were collected together with the thrived tufts of small Bryopsis sp. on the coral reef of intertidal zone.

Among the specimens at hand, two tufts are mature. The tuft has a few axes, which are erect, subcylindrical, maximal $2.7 \mathrm{~mm}$ and ordinary $1.5-2.0 \mathrm{~mm}$ in height, simple or rarely dichotomously branched in the upper portion, gradually tapering upward until the apex.

The ramuli, issuing on all side generally, cover the axis softly and densely except on some range of the lower portion of the axis. Simple and subcylindrical ramuli are $1.2-1.8 \mathrm{~mm}$ long and $31-39 \mu$ broad in the lower part, $18-23 \mu$ at the apex. At the bases they are narrowed.

The gametangium is obovate or spherical in shape and mucronated characteristically. It is borne almost singly at the basal portion of ramulus near the axis.

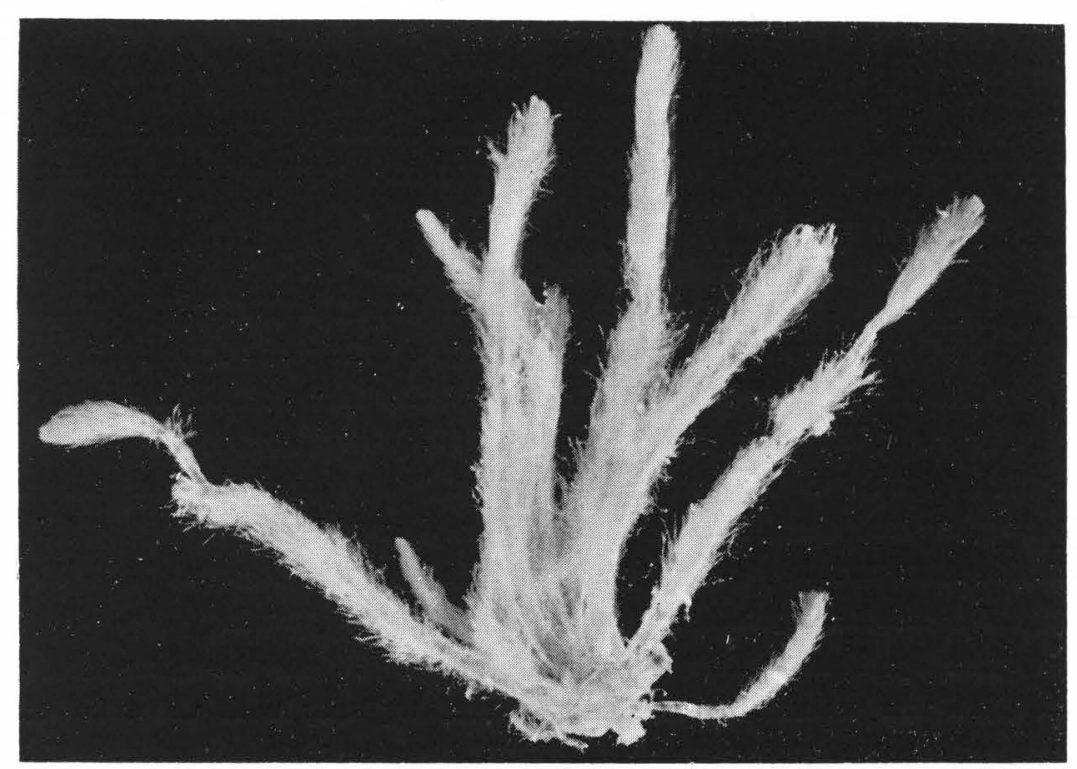

Fig. 2. A tuft of Pseudobryopsis hainanensis TSENG. $\times 4$ 


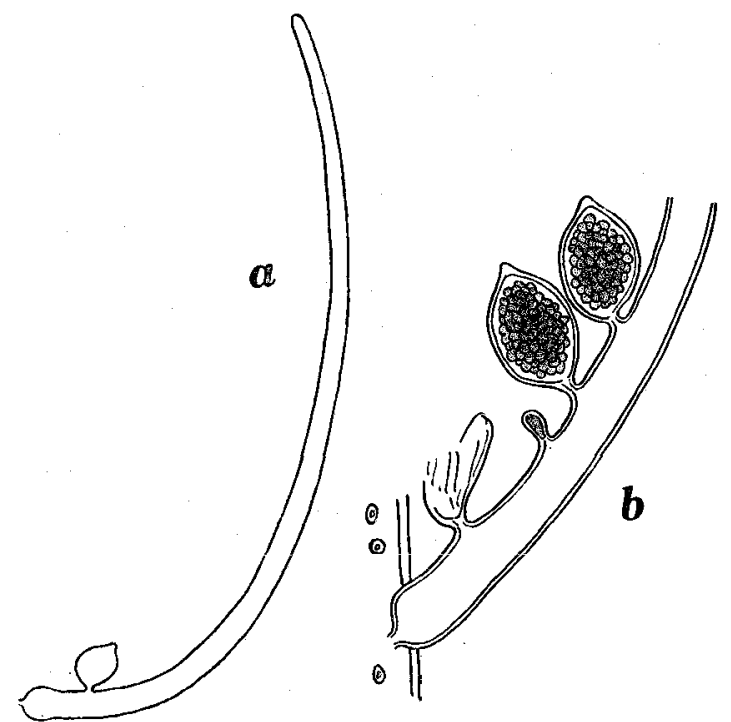

Fig. 3. Pseudobryopsis hainanensis TSENG.

a. A ramulus bearing a single gametangrum near its base. $\times 75$

$b$. Two matured gametangium and ruptured remain on the same ramulus. $\times 150$

Occasionally two or more gametangia and remnant bases are seen at the base of ramulus. They are $60-90 \mu$ long, $45-60 \mu$ in diameter. Pyrenoids are present in the $2-3 \mu$ broad chromatophores.

In comparison with other species of this genus, this specimen coincides well with Pseudobryopsis hainanensis TSENG in dimensions as shown in Table 1. As seen from the above description, however, our plant differs from his plant in having more than one gametangium on the ramulus. On the other hand, the material of Isla San Benedicto recognized as P. hainanensis by DAwSON (1954) also have the same feature as our plant with regards to the gametangium numbers on the ramulus. Accordingly my plant should be considered as $P$. hainanensis, and so it seems to be not infrequent that the ramuli have not only single gametangium but two or more.

Although the original specimen was described to be growing on the root of a Rhizophora plant by TSEng, DAwson's plant was found on the fresh lava of San Benedicto. Mine was presumably on the coral reef together with the tufts of small Bryopsis sp., and there growing no Rhizophora plant at Takarazima. So, it is probable that this species does not always grown on the root of Rhizophora plant. 
Table 1.

\begin{tabular}{|c|c|c|c|c|c|c|}
\hline \multirow[b]{2}{*}{ Species } & \multirow{2}{*}{$\begin{array}{l}\text { Height } \\
\text { of axis } \\
(\mathrm{cm})\end{array}$} & \multirow{2}{*}{$\begin{array}{c}\text { Width of stem } \\
(\mu)\end{array}$} & \multirow{2}{*}{$\begin{array}{l}\text { Length } \\
\text { of ra- } \\
\text { mulus } \\
\text { (mm) }\end{array}$} & \multirow{2}{*}{$\begin{array}{c}\text { Width of ramulus } \\
(\mu)\end{array}$} & \multicolumn{2}{|c|}{$\begin{array}{c}\text { Size of } \\
\text { gametangium }\end{array}$} \\
\hline & & & & & $\begin{array}{c}\text { Width } \\
(\mu)\end{array}$ & $\begin{array}{c}\text { Length } \\
(\mu)\end{array}$ \\
\hline $\begin{array}{c}\text { Pseudobryopsis hainanensis } \\
\text { (after TSENG, 1936) }\end{array}$ & 2.2 & $\begin{array}{l}500(\text { lower part }) \\
100(\text { upper part })\end{array}$ & 1.2 & $\begin{array}{l}30-36 \text { (lower part) } \\
18-22 \text { (tip) }\end{array}$ & $36-52$ & $52-7.8$ \\
\hline $\begin{array}{r}P . \quad \text { mauritiana } \\
\text { (after BörgesEN, 1948) }\end{array}$ & 10 & 400 & 1.0 & $70-80$ & 125 & 200 \\
\hline $\begin{array}{c}\text { mucronata } \\
\text { (after BörgESEN, 1930) }\end{array}$ & 5.0 & 250 & & & & \\
\hline$P . \quad$ Myura & 5.0 & & & $\begin{array}{l}100(\text { lower part }) \\
25-30(\text { tip })\end{array}$ & 30 & 50 \\
\hline $\begin{array}{r}\text { P. } \\
\quad \text { (after EGEROD }, 1952)\end{array}$ & $3-5$ & $400-500$ & 2.5 & 30 & $60-75$ & $135-150$ \\
\hline $\begin{array}{rr}P . & \text { papillata } \\
& \text { (after NASR, 1944) }\end{array}$ & 15 & 1000 & 4.0 & 50 & $50-65$ & $70-90$ \\
\hline$P . \underset{\text { (after Dawson, 1954) }}{\text { parva }}$ & $0.5-0.7$ & $\begin{array}{l}100 \text { (at the base) } \\
25-15 \text { (tip) }\end{array}$ & $1.0-1.5$ & 20 & $35-50$ & 190 \\
\hline Present specimen & $\begin{array}{c}2.7 \\
(\max .)\end{array}$ & $\begin{array}{l}700(\text { lower part) } \\
300 \text { (upper part) }\end{array}$ & 1.8 & $\begin{array}{l}\text { 31--39(lower part) } \\
18-23 \text { (tip) }\end{array}$ & $45-60$ & $60-90$ \\
\hline
\end{tabular}

\section{Coelarthrum coactum OKamURA et SEgawa}

(Fig. 4)

Segawa, Mar. Alg. Susaki, Prov. Izu, II (1936), p. 186, fig. 7.

Japanese Name. Sujiko-nori (nov.)

Though all sterile, somewhat numerous materials, drifted ashore by storm, were collected.

The present specimens almost agree with the description and illustration given by SEgawa (1936) in every way, although different in some points.
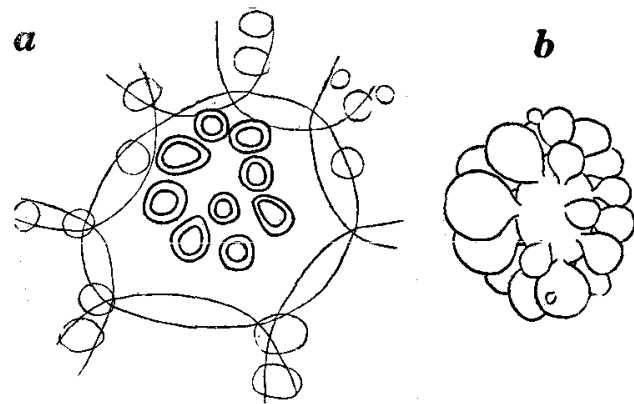

Fig. 4. Coelarthrum coactum OKamuRA et SEgawa.

$a$. Gland cells ornated on inner large cells seen

from the cavity. $\times 200$

b. Specimen somewhat regularly ramified. $\times 1$ 
In the specimens at hand, the gland cells appear on normal large cells usually more numerous than in his plant. There exist, of course, such gland cells as described in the original paper. Furthermore, the mode of ramification in the frond of one specimen is rather regular, that is, small vesicles issue from the central large one somewhat radially. Near the diaphragms, the membrane is composed of three sorts of layers; small 2 to 3 -celled cortical layer, large one-celled middle layer and small one-celled innermost layer.

\section{Erythrocolon podagricum (HARVEY) J. AGARDH}

(Fig. 5)

YAMAdA and TANAKA, Mar. Alg. Isla. Yonakuni (1938), p. 78, figs. 10-11.

Japanese Name. Hime-hukurotunagi.
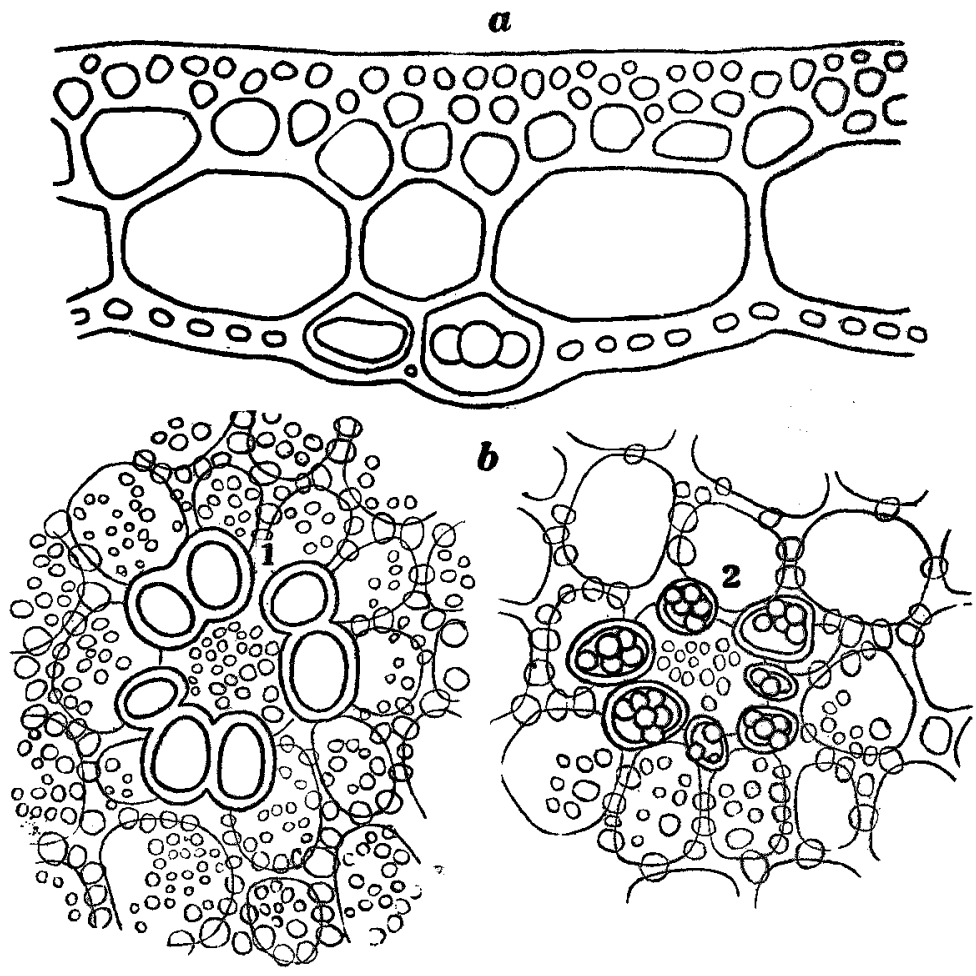

Fig. 5. Erythrocolon podagricum (HARvex) J. AGARDH.

a. Transverse section of frond with two sorts of gland cells. $\times 300$

b. Inner surface with gland cells facing the cavity. $\times 180$

1. Ordinary gland cells. 2. Gland cells of which content is divided in to granules of iridescent substance. 
A few specimens from Tokara which are sterile seem to coincide well with the description and illustration of YAMADA and TANAKA.

The Tokara specimens have two sorts of gland cells. One is the same as that of the Yonakuni specimens, the other somewhat different. In gland cell of the latter, the content is divided into some iridescent granules. In the present materials also, the assemblies of ordinary gland cells, grouping in 5-8, ornated on the cell of innermost layer, are frequent and those in form of the latter sort are rare. In a few cases these two sorts of gland cells are found mixed in one colony. 